\title{
DIET AND REPRODUCTIVE ASPECTS OF THE EXOTIC GECKO GEHYRA MUTILATA (WIEGMANN, 1834) (SAURIA: GEKKONIDAE) IN THE URBAN AREA OF CHAPALA, JALISCO, MEXICO
}

\author{
José Luis BARRAGÁN-RAMÍREZ*, OMAR EduARdo REYES-LUIS*, JosÉ de Jesús ASCENCIO-ARRAYGA, \\ José LuIS NAVARRETE-HEREDIA \& Miguel VÁSQUEZ-BOLAÑOS
}

\author{
Centro de Estudios en Zoología, CUCBA, Universidad de Guadalajara. Apartado postal 134, 45100 Zapopan, \\ Jalisco, México. <barragan5478@yahoo.com.mx>; <vetom89@gmail.com>
}

Recibido: 28/05/2014; aceptado: 22/09/2014

Barragán-Ramírez, J. L., Reyes-Luis, O. E., Ascencio-Arrayga, J. J., Navarrete-Heredia, J. L.\& Vasquez-Bolaños, M. 2015. Diet and reproductive aspects of the exotic gecko Gehyra mutilata (Wiegmann, 1834) (Sauria: Gekkonidae) in the urban area of Chapala, Jalisco, Mexico. Acta Zoológica Mexicana (n. s.), 31(1): 67-73.

ABSTRACT. We studied the diet and described some reproductive aspects (body size, clutch size, size and egg volume, and nesting site) of the exotic gecko Gehyra mutilata in the urban area from Chapala, Jalisco, Mexico, during a period of nine months (April-December, 2013). A total of 113 adult individuals were captured, where 101 revealed to have stomach contents. We found a total of 1,563 food items, which were identified and grouped into 13 prey categories: Araneae, Blattodea, Coleoptera, Dermaptera, Diptera, Gastropoda, Hemiptera, Hymenoptera: Formicidae and Non-Formicidae, Isopoda, Lepidoptera, Orthoptera, Squamata (Gekkonidae) and Trichoptera. Diptera (Nematocera) was the most important food category in abundance (91.6\%), relative frequency (34.2\%), volume (68.8\%), and relative importance (94.8\%). Other uncountable food items as plant material and eggshell remains were present in the diet. The number of prey per stomach were between 1 to 140 , with a mean of $15.5 \pm 25.56$, the prey volume mean was $0.29 \pm 0.76 \mathrm{ml}$, with a range of $<0.01-2.90 \mathrm{ml}$. Males had fewer prey items in their stomachs than females, but no significant differences were found between sexes. Diet diversity $\left({ }^{1} D\right)$ between males and females was evaluated, which was similar with almost two effective food categories for both sexes. The trophic niche overlap between sexes showed a high numeric and volumetric similarity in their diet. Snout-vent length did not significantly differ between males and adult females. The mean clutch size was 2 eggs, even though the nesting site can be composed of larger egg clusters. The nesting sites consisted on holes, crevices and inside electric installations on building walls. The mean egg length was $10.47 \pm 0.541$, with a mean width of $8.40 \pm$ 0.256 , while the mean volume was $387.92 \pm 43.297 \mathrm{~mm}^{3}$. The present study suggests that the opportunist habits of G. mutilata are a determinant factor on its diet composition within the urban area of Chapala. Key words: feeding ecology, exotic species, oviposition, clutch size, egg size, body size, nest site.
Barragán-Ramírez, J. L., Reyes-Luis, O. E., Ascencio-Arrayga, J. J., Navarrete-Heredia, J. L.\& Vasquez-Bolaños, M. 2015. Dieta y aspectos reproductivos del gecko exótico Gehyra mutilata (Wiegmann, 1834) (Sauria: Gekkonidae) en la zona urbana de Chapala, Jalisco, México. Acta Zoológica Mexicana (n. s.), 31(1): 67-73.

RESUMEN. Se estudió la dieta y se describen algunos aspectos reproductivos (tamaño corporal, tamaño de puesta, tamaño y volumen del huevo, y sitio de puesta) del gecko exótico Gehyra mutilata en la zona urbana de Chapala, Jalisco, México, durante un período de nueve meses (abril - diciembre de 2013). Un total de 113 individuos adultos fueron capturados, de los cuales 101 presentaron contenido estomacal. Se contabilizaron un total de 1,563 artículos alimenticios, los cuales fueron identificados y agrupados en 13 categorías de presas: Araneae, Blattodea, Coleoptera, Dermaptera, Diptera, Gastropoda, Hemiptera, Hymenoptera: Formicidae y no Formicidae, Isopoda, Lepidoptera, Orthoptera, Squamata (Gekkonidae) y Trichoptera. Diptera (Nematocera) fue la categoría de alimento más importante en abundancia (91.6\%), frecuencia relativa (35.2\%), volumen (68.8\%) e importancia relativa (94.8\%). Otros elementos incuantificables como materia vegetal y fragmentos de cascarón estuvieron presentes en la dieta. El número de presas por estómago osciló entre 1 y 140, con una media de 15.5 \pm 25.56 ; el volumen promedio de las categorías de presa fue de 0.29 $\pm 0.76 \mathrm{ml}$, con un rango de $<0.01$ a $2.90 \mathrm{ml}$. Los machos presentaron menos presas en sus estómagos que las hembras, aunque no se encontraron diferencias significativas entre sexos. La diversidad de la dieta $\left({ }^{1} D\right)$ entre machos y hembras fue similar para ambos sexos, con casi dos categorías de alimento efectivas. El solapamiento de nicho trófico entre sexos mostró una alta similitud numérica y volumétrica. Por su parte, la longitud hocico-cloaca no mostró diferencias significativas entre sexos. El tamaño de puesta en promedio fue de dos huevos, aunque la nidada puede estar constituida por agregaciones de más huevos. Los sitios de puesta consisten en huecos y grietas en muros, así como el interior de instalaciones eléctricas. El tamaño del largo del huevo fue de $10.47 \pm 0.54$ en promedio, con una anchura promedio de 8.40 \pm 0.256 , mientras que el volumen fue de $387.92 \pm 43.30 \mathrm{~mm}^{3}$. Este estudio sugiere que los hábitos oportunistas de G. mutilata son un factor determinante en la composición de su dieta dentro de la zona urbana de Chapala.

Palabras clave: ecología alimenticia, especie exótica, ovoposición, tamaño de puesta, tamaño del huevo, tamaño corporal, sitio de nidada. 


\section{INTRODUCTION}

Exotic species constitute a great problem for natural environments and for native species, threatening its integrity and existence. According to some authors (Breithaupt 2003; Park 2004), the introduction of exotic species is considered the second greatest threat to global biological diversity after habitat destruction, causing the loss of biodiversity and extinctions in most areas worldwide. The rapid spread of some exotic species is creating complex and far-reaching challenges that threaten both the natural biological world and the human wellbeing (McNeely et al. 2001). In Mexico orientated actions have been taken to prevention, control and eradication of invasive species, reason why the government created "the national strategy on invasive species", where an essential part is the generation of knowledge to prevent and understand the problems and consequences that generate the exotic and invasive species, allowing us to understand aspects of their ecology and interaction with the environment.

The gecko Gehyra mutilata (Wiegmann, 1834) (Fig. 1) is a widely distributed species in the Pacific Basin, large regions of Southeast Asia, and the Indian Ocean (Fisher 1997). This species is an effective colonizer and nocturnal predator, usually associated with human buildings. It is an oviparous species, without a pronounced seasonal reproductive cycle (Church 1962), producing clutches of two eggs (Schwaner 1980; Sabath 1981). Its diet consists mainly on arthropods, like many other invasive geckos, such as Hemidactylus frenatus Schlegel, 1836, $H$. mabouia (Moreau de Jonnés, 1818) and H. turcicus (Linnaeus, 1758) (Álvarez-Romero et al. 2008). Molecular studies by Fisher (1997) and more recently by Rocha et al. (2009) have indicated that the Pacific and the Asian / Indian Ocean populations represent two cryptic lineages within G. mutilata.

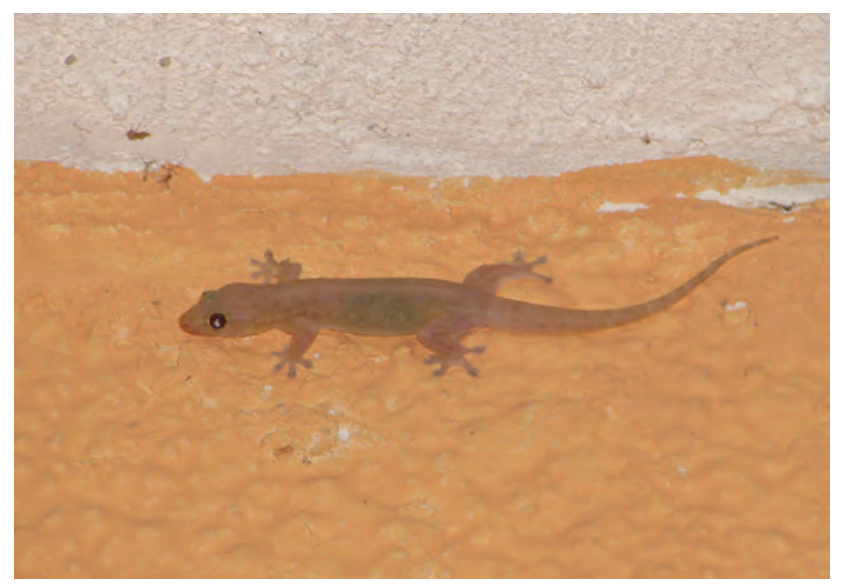

Figure 1. An adult specimen of Gehyra mutilata in a wall outside a building, looking for prey near a light source.
In Mexico, G. mutilata is an exotic species known of the states of Baja California Sur (Reynoso 1990), Chiapas (Álvarez del Toro 1983), Nayarit (Dugès 1883; Smith \& Taylor 1950; Flores-Villela et al. 1991; Quijada-Mascareñas \& Canseco-Márquez 2007), Jalisco (Smith \& Grant 1958; Flores-Villela et al. 1991; Ponce-Campos \& Huerta-Ortega 2001), Guerrero (Flores-Villela et al. 1991), San Luis Potosí (Lemos-Espinal \& Dixon 2013) and Sinaloa (Smith \& Taylor 1950; Hardy \& McDiarmid 1969). However, despite its presence in Mexican territory and its continued expansion, aspects of its ecology are unknown, without considering the impact that it may be causing on the environment and native fauna. So, the purpose of this study was to describe the feeding ecology of an urban population of Gehyra mutilata, in Chapala, Jalisco, Mexico. Additionally, we describe and compare some reproductive aspects as the body size, clutch size, size and egg volume, hatchling size and nest site.

\section{MATERIALS AND METHODS}

We used Internet databases (Google scholar, Web of Science, JSTOR and SCOPUS) to search for published studies about diet composition and reproduction of $G$. mutilata, starting from 1960 to 2014. Search date and data were collected on 17 March 2014. Synonymies were used to cover all the names known for this species.

The study was carried out from April to December 2013 in the urban area of Chapala $\left(20.290430^{\circ} \mathrm{N}\right.$, $103.190310^{\circ} \mathrm{W}, 1535 \mathrm{~m}$ elevation; DATUM = WGS84), near Chapala's Lake, in Jalisco, Mexico (Fig. 2). During each month a minimum of twelve individuals of $G$. mutilata were captured, which resulted in a total of 113 adult specimens. All geckos were encountered on the wall of human housing, and were collected by hand between 20:00-23:00 h. Specimens captured were immediately transferred to a plastic container containing cotton embedded in ether, in order to anesthetize and euthanize them, hours later were preserved in $90 \%$ ethanol. In the laboratory, we measured the snout-vent length (SVL) of each individual with a digital caliper (MasterCraft ${ }^{\circledR}$; to $0.01 \mathrm{~mm}$ ). Sex was determined by secondary sexual characters; presence of well developed femoral pores in males and poorly developed femoral pores in females, and finally by gonadal identification after dissection. Reproductive condition (adult age) of the specimens was confirmed following the criteria used in Sabath (1981). We removed the stomachs through a ventral longitudinal incision for their posterior content analyses under a stereomicroscope. For analyses, we only considered the items present in the stomachs. Prey items were determined to the lowest possible taxonomic level, counted and stored in $70 \%$ ethanol. 


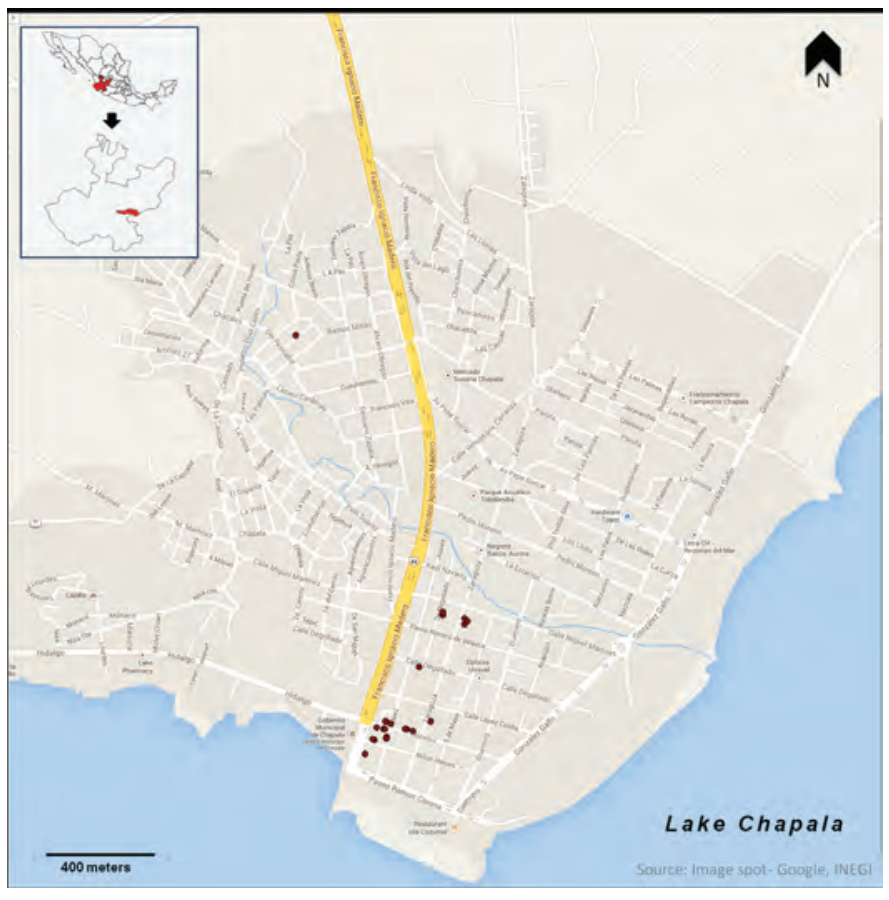

Figure 2. Map of the study area showing the sampling locations in the urban area of Chapala, Jalisco, Mexico.

The contents that could not be identified were pooled into a "non-identified" category. The stomach contents determination was performed at the Entomological collection, Centro de Estudios en Zoología, Universidad de Guadalajara (CZUG), where they were deposited.

The number of items was defined as the amount of prey of a given food item in the total diet, and the frequency of occurrence of each food item was defined as the total number of stomachs in which a given item was found. The volume of each food category was estimated by fluid displacement to the nearest $0.1 \mathrm{ml}$ (Magnusson et al. 2003). The importance of each food category consumed $(t)$ was described by the index of relative importance (Pianka et al. 1971; Pianka 1973), which was calculated as $I R I_{t}=\left(P O_{t}\right)\left(P I_{t}+P V\right)$, where $P O_{t}$ is the percentage of occurrence (100 x number of stomachs contained $t$ item divided by total number of stomachs), $P I_{t}$ is the percentage of individuals (100 x total number of individuals of $t$ in all stomachs divided by total number of individuals of all taxa in all stomachs), and $\mathrm{PV}_{\mathrm{t}}$ is the percentage of volume (100 x total volume of individuals of $t$ in all stomachs divided by total volume of all taxa in all stomachs). Diet diversity was estimated with the method proposed by Jost (2006), who recognizes the "true diversity" (the effective numbers of types). For this analysis, we only considered the diversity of order one, ${ }^{1} D=\exp \left(H^{\prime}\right)$, were ${ }^{1} D$ is the true diversity, and $\exp \left(H^{\prime}\right)$ is the exponential of Shannon’s entropy index (Jost 2006; Moreno et al. 2011).
Pianka's index of niche overlap (Pianka 1974) was used to determine diet similarity among adult males and adult females of G. mutilata using the software ECOSIM 7.0 (Gotelli \& Entsminger 2001). This index varies between 0 (no overlap) and 1 (complete overlap). The Mann-Whitney $\mathrm{U}$ test was performed to analyze differences in SVL and number of food items consumed by males and females.

Clutch size was calculated from oviductal eggs count, data about nest and egg clutches were collected whenever it was possible to locate them. The eggs size and hatching size was determined, using a digital caliper to $0.01 \mathrm{~mm}$, while the egg volume was determined using the formula for a prolate spheroid: volume $=4 / 3 \pi$ (length $/$ 2)*(width/2) ${ }^{2}$

\section{RESULTS}

Database search for biological information for this species was unsuccessful. No reference exists for diet details whereas few (less than five articles) were found for reproduction information (Chou 1979; Church 1962; Quay 1974; Sabath 1981).

Diet. We collected 113 adult individuals of G. mutilata from April to December 2013. Of these, 101 lizards (44 males and 57 females) contained food in their stomachs. A total of 1,563 prey items were analyzed (mean per stomach $=15.47, \mathrm{SD}=25.56$, range $=1-140$ ), which were classified into five taxonomic groups (Arachnida, Crustacea, Insecta, Mollusca, and Reptilia) and 13 food categories, where Hymenoptera order was divided into two distinct subcategories: Formicidae and Non-Formicidae (Table 1). Members of the family Formicidae were further classified into seven genera, and four species (Table 1). In terms of number, the order Diptera was the most important food category with 1432 individuals (91.67\%), followed by Araneae $(n=71)$, which comprised $4.55 \%$ of the total number of prey items. The rest of the food categories presented less than $1 \%$ of relative abundance each. Volume of prey categories ranged from $<0.01-2.90 \mathrm{ml}$ (mean $\pm \mathrm{SD}=0.29 \pm 0.76 \mathrm{ml}$ ). The order Diptera contributed about $69 \%$ of the total volume of prey items (2.90 $\mathrm{mL}$ ), followed by G. mutilata remains with $10 \%$ (Table $1)$. The most frequent prey items were Diptera and Araneae, recorded in 69 (35.75\%) and 43 (22.28\%) stomachs, respectively. Additionally, we found unquantifiable items (plant material, eggshell remains and parts of invertebrates) in the diet of G. mutilata, which constituted a separate group called "Other items". Plant matter was found in two stomachs (1.04\%), invertebrate parts unidentified were found in twenty-four stomachs (12.44\%), as well as $G$. mutilata eggshell remains consumed by a female. 


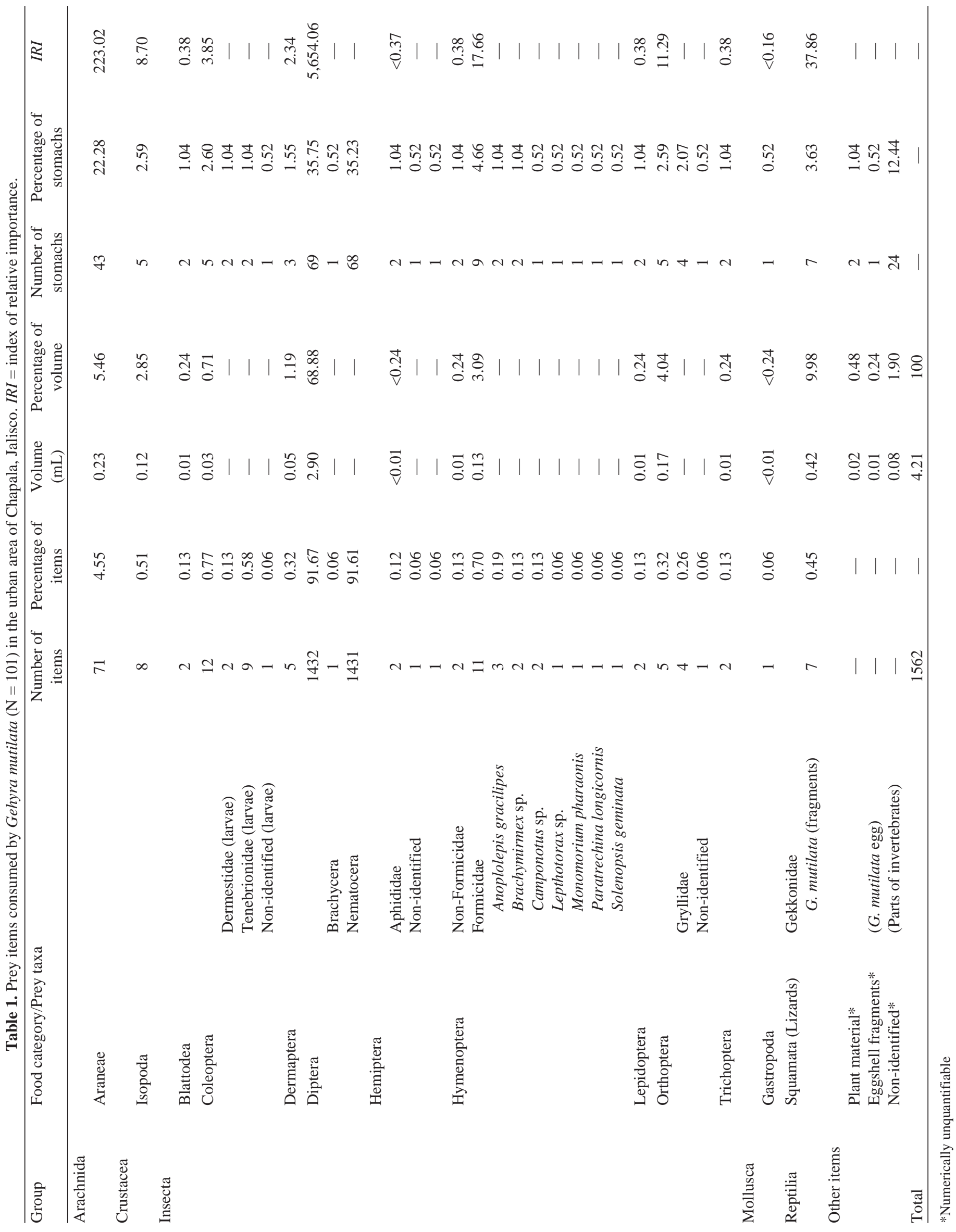


According to the Index of Relative Importance (IRI), the most important food category in the diet of G. mutilata was Diptera $\left(I R I_{t}=5,654.06=94.85 \%\right)$, followed by Araneae $\left(I R I_{t}=223.02=3.74 \%\right)$. The rest of the items had lower relative importance indexes (Table 1).

The mean number of food items consumed by adult females was higher $(18.96 \pm 27.87$, range $=1-140)$ in comparison to males (13.15 \pm 22.48 , range $=1-103$ ), but no significant difference was found (Mann-Whitney U test $=939.5, \mathrm{Z}=-1.26, \mathrm{P}=0.207$ ). Diet diversity between sexes was evaluated, ${ }^{1} D=1.641$ for males and 1.489 for females, which was similar representing almost two effective food categories for both sexes. The trophic niche overlap between males and females (concerning number of prey items) by Pianka's index $\left(O_{j k}\right)$ was high, with a value of 0.82 and observed variance of 0.05 . Regarding volume of food categories, the similarity was high between sexes $\left(O_{j k}=0.84\right.$; observed variance $\left.=0.05\right)$. The categories with greater volume consumed by both females and males were Diptera (ठ 72.85\%; ᄋ 67.16\%), G.

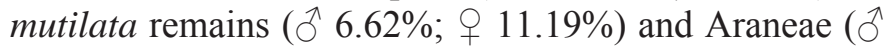
$6.62 \%$; + $4.85 \%$ ). The IRI of feeding items revealed Diptera is the most important item in the diet of adult males and females ( $I R I_{t}=0.93$ and 0.90, respectively).

Reproductive aspects. From the total specimens collected (51 males and 62 females, $N=113$ ) during the sampling period, males showed a SVL range between 40.18 and $59.38 \mathrm{~mm}$ (mean $\pm \mathrm{SD}=52.03 \pm 4.29$ ), and females from 41.25 to $59.55 \mathrm{~mm}$ (mean $\pm \mathrm{SD}=50.82 \pm 4.58$ ). No significant sexual dimorphism was found in the SVL of adults (Mann-Whitney U test $=1307.5, \mathrm{Z}=-1.446$, $\mathrm{P}$ $=0.148$ ). Twelve females showed oviductal eggs (mean eggs per lizard $=1.92, \mathrm{SD}=0.51$, range $=1-3$ ); two of them had one egg, one had three eggs, while the remaining individuals had two eggs. The smallest female with oviductal eggs had $46.8 \mathrm{~mm}$ SVL. Gravid females and hatchlings were observed during all months of the sampling period. Additionally, we found eleven eggs clutches of G. mutilata, five of which consisted in aggregations of more than two eggs (Table 2; Fig. 3).

We incubated one of the egg clutches $(n=10)$, collected on April 25 2013 at a temperature between 25 - 28 ${ }^{\circ} \mathrm{C}$. Three eggs hatched, two on May 27 and one on May $29^{\text {th }}$ 2013, after an incubation time of 32 and 34 days, respectively. Mean hatchling SVL was $21.94 \mathrm{~mm}$ (SD = 0.66 , range $=21.22-22.52 \mathrm{~mm}$ ).

A total of 30 eggs from different clutches were measured, all of which were white, calcareous, subspherical, and adhesive. The egg length range was $9.37-11.45 \mathrm{~mm}$ (mean $\pm \mathrm{SD}=10.47 \pm 0.54$ ); width range was $7.87-8.94$ $\mathrm{mm}$ (mean $\pm \mathrm{SD}=8.40 \pm 0.26$ ) and volume range was 303.87 to $479.16 \mathrm{~mm}^{3}$ (mean $\pm \mathrm{SD}=387.92 \pm 43.30$ ).

\section{DISCUSSION}

We considered that the population of Gehyra mutilata from Chapala showed an opportunistic diet, despite being a generalist species. Diptera (Nematocera) was the most important prey item in the diet of this species; mosquitoes present a high proliferation in the vicinity of Lake Chapala during most of the year. Also, the attraction of Diptera by the artificial lights of the urban environment, along with low richness and availability of other prey types, lead $G$. mutilata to concentrate mainly on one category of prey. This fact has been documented in other diet studies of lizards conducted in urban environments, where flying groups of arthropods (such as lepidopterans and dipterans) have a higher number and frequency of occurrence in the diet of geckos (e.g. Klawinski et al. 1994; Saenz 1996; Bonfiglio et al. 2006; Díaz-Pérez et al. 2012). Araneae was the second important food category in the diet, in terms of number and frequency, probably as a result of geckos hunting arthropods attracted to light sources.

The vast majority of preys in this study were arthropods, but unquantifiable items like plant material and eggshell remains were found. Fragments of vegetal material found in stomachs of $G$. mutilata were probably accidentally ingested during prey capture, due to its low

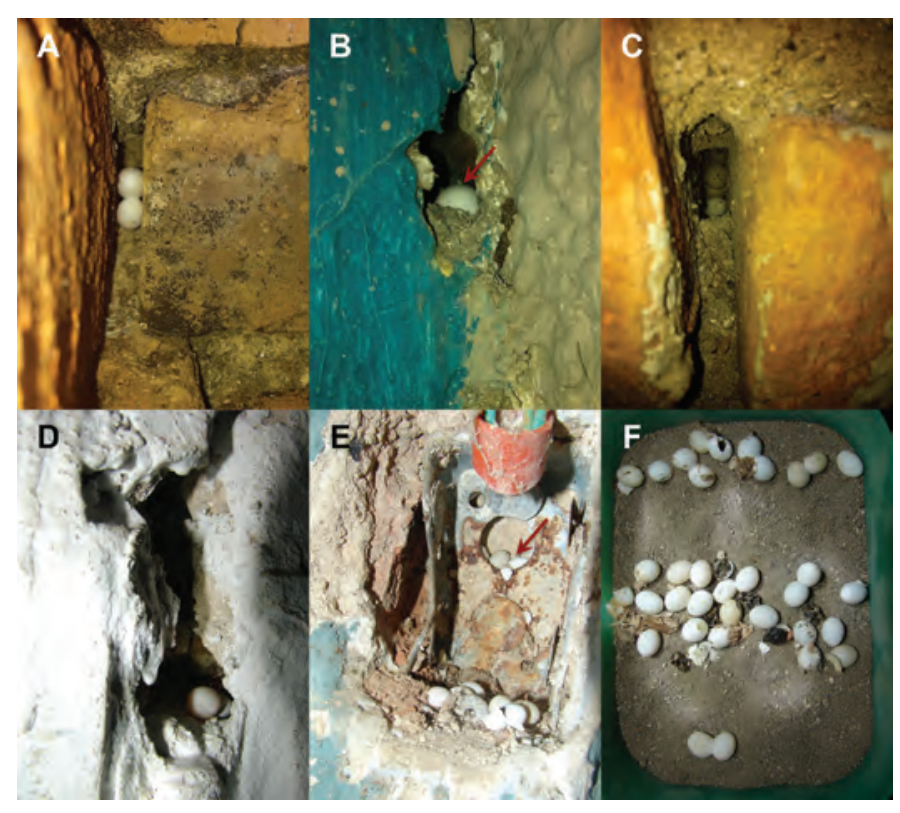

Figure 3. Gehyra mutilata nests found inside buildings in the urban area of Chapala, Jalisco. A) A pair of eggs found on a small crevice on a brick wall. B) A pair of eggs found on a crevice on the wall. C) A clutch of five eggs found on a crevice on a brick wall. D) A pair of eggs found on a crevice on a wall. E) Clutch of twenty-seven eggs found behind an electric box. F) Upper. A clutch of twelve eggs found inside an electric box. Middle. Clutch of twenty-seven eggs (described on letter E). Bottom. A pair of eggs found inside an electric box. 
Table 2. Summary of information on Gehyra mutilata egg clutches encountered in the vicinity of Chapala, Jalisco.

\begin{tabular}{|c|c|c|c|c|c|}
\hline \multirow[t]{2}{*}{ Date } & \multirow[t]{2}{*}{ Image } & \multirow[t]{2}{*}{ Location } & \multicolumn{3}{|c|}{ Number of eggs } \\
\hline & & & Intact & Eggshells & Total \\
\hline 20/04/2013 & Fig. 3E \& 3F (Middle) & Behind an electric box outside a house. & 20 & 7 & 27 \\
\hline $21 / 04 / 2013$ & Fig. 3F (Upper) & Inside an electric box for a telephone line inside a house. & 10 & 2 & 12 \\
\hline 25/04/2013 & - & In a crevice inside a bathroom. & 1 & 1 & 2 \\
\hline 23/10/2013 & Fig. 3C & In a crevice on the wall (outside). & 5 & 0 & 5 \\
\hline 20/11/2013 & - & In a crevice on the wall (outside). & 3 & 2 & 5 \\
\hline 20/11/2013 & Fig. 3A & In a crevice on the wall, behind a water heather (outside). & 2 & 0 & 2 \\
\hline $21 / 11 / 2013$ & Fig. 3D & In a crevice on the wall (inside). & 2 & 0 & 2 \\
\hline
\end{tabular}

frequency and volume. Additionally, we found the presence of eggshell remains in the stomach of a female, a fact that has been documented in other studies with gekkonids (Church 1962; Kusuminda et al. 2013), which may be related to the absorption of minerals. Intraspecific predation (cannibalism) was present in this species, which might represent an opportunistic feeding behavior according to prey availability, a practice that has been documented in other gekkonid species (Bonfiglio et al. 2006; Locey \& Stone 2008; Sanchez 2010; Díaz-Pérez et al. 2012). Also in terms of volume, G. mutilata fragments constituted an important item in the diet of this species.

The composition and abundance of $G$. mutilata diet did not vary between adult males and females, resulting in a similar dietary composition, volumetric overlap, and low diversity of prey categories between sexes, which can be explained by the high availability of dipterans (Nematocera) in the study area, especially near light sources, where individuals of both sexes come to feed at the same time of activity. Also, there were no significant size differences (snout-vent length) between adult males and females, consistent with SVL reported in studies of other populations of the same species (Church 1962; Sabath 1981), and which could be related to the high trophic niche overlap found between the sexes. Mean SVL of males and females in this study are similar to that recorded by Church (1962) and Quay (1974), in populations from Bandung, West Java province, Indonesia, and Kauai, Hawaiian Islands, respectively. In contrast, Sabath (1981) reported a mean SVL of $46.6 \mathrm{~mm}$ for females (range $=42-50 \mathrm{~mm}$, $n=13$ ) and $45.7 \mathrm{~mm}$ for males (range $=39-51 \mathrm{~mm}, n=$ 17) from Guam, Mariana Islands, which are smaller indi- viduals than those studied by us. This difference may be attributed to many factors (e.g. size, abundance and density of prey) (Case \& Schwaner 1993; Jessop et al. 2006), including environmental and genetic considerations, but we lack of specific details for G. mutilata.

Gehyra mutilata females reach reproductively mature at a SVL of $40 \mathrm{~mm}$ in the American Samoa islands (Schwaner 1980). In our study something similar occurred, the smallest adult female found was $41.25 \mathrm{~mm}$ and the smallest with oviductal eggs was $46.8 \mathrm{~mm}$ (SVL). Egg sizes (length and egg width), were similar to that reported by Chou (1979) in Singapore. Concerning egg aggregations, it is difficult to know whether this is a communal nesting or it is due to repeated use by individual females (Bock 1996), or even a combination of both. Moreover, the presence of juveniles and females with oviductal eggs during all months of the sampling period suggest reproductive activity most of the year.

Finally, it is important to mention that the exotic gecko G. mutilata could potentially play an important role in the control of dipterans (Nematocera) in the urban area of Chapala, however, it is necessary to carry out further studies to assess the impact of this species in this and other areas of Mexico. Until now, this study represents a first step into evaluating ecological effects of a nonnative population of gecko.

Acknowledgements. We are highly grateful to many people who supported us during the course of this study. We want to especially thank the owners of the Zapote restaurant and Hotel Villa Samary, who supported us during the course of fieldwork. We also thank to Mrs. María de Jesús Rivera Zúñiga, who gave us their support and friendship at all times. 


\section{LITERATURE CITED}

Álvarez del Toro, M. 1983. Los reptiles de Chiapas. Third edition. Instituto de Historia Natural, Tuxtla Gutiérrez, Chiapas, 248 pp.

Alvarez-Romero, J. G., Medellín, R. A., Oliveras de Ita, A., Gómez de Silva, H. \& Sánchez, O. 2008. Animales exóticos en México: una amenaza para la biodiversidad. Comisión Nacional para el Conocimiento y Uso de la Biodiversidad, Instituto de Ecología, UNAM, Secretaría de Medio Ambiente y Recursos Naturales, México, D.F., 518 pp.

Bock, B. C. 1996. Interclutch interval and egg aggregations in the tropical house gecko, Hemidactylus mabouia. Herpetological Review, 27: 181-183.

Bonfiglio, F., Balestrin, R. L. \& Cappellari, L. H. 2006. Diet of Hemidactylus mabouia (Sauria, Gekkonidae) in urban area of southern Brazil. Biociências, 14: 107-111.

Breithaupt, H. 2003. Aliens on the shores. EMBO reports, 4: 547550.

Case, T. J. \& Schwaner, T. D. 1993. Island/mainland body size differences in Australian varanid lizards. Oecologia, 94: 102-109.

Chou, L. M. 1979. Eggs and incubation period of three gekkonid lizards. Copeia, 1979: 552-554.

Church, G. 1962. The reproductive cycles of the Javanese house geckos, Cosymbotus platyurus, Hemidactylus frenatus, and Peropus mutilates. Copeia, 1962: 262-269.

Díaz-Pérez, J. A., Dávila-Suárez, J. A., Alvarez-García, D. M. \& Sampedro-Marín, A. C. 2012. Dieta de Hemidactylus frenatus (Sauria: Gekkonidae) en un área urbana de la región Caribe Colombiana. Acta Zoológica Mexicana (n. s.), 28: 613-616.

Dugès, A. 1883. Una nueva especie de salamanquesa (Hemidactylus navarri, A. Dugès). La Naturaleza, 6: 309-312.

Fisher, R. N. 1997. Dispersal and evolution of the Pacific Basin gekkonid lizards Gehyra oceanica and Gehyra mutilata. Evolution, 51: 906-921.

Flores-Villela, O. A., Hernández-García, E. \& Nieto-Montes de Oca, A. 1991. Catálogo de anfibios y reptiles. Serie Catálogos del Museo de Zoología “Alfonso L. Herrera”, No. 3. Coordinación de Servicios Editoriales, Facultad de Ciencias, UNAM, México, D.F., 222 pp.

Gotelli, N. J. \& Entsminger, G. L. 2001. EcoSim: Null models software for ecology. Version 7.0. Acquired Intelligence Inc. \& Kesey-Bear.

Grismer, L. L. 2002. Amphibians and reptiles of Baja California. University of California Press, Berkeley, California, 399 pp.

Hardy, L. M. \& McDiarmid, R. W. 1969. The amphibians and reptiles of Sinaloa, Mexico. University of Kansas Publications, $\mathrm{Mu}$ seum of Natural History, 18: 110-111.

Jessop, T. S., Madsen, T., Sumner, J., Rudiharto, H., Phillips, J. A. \& Ciofi, C. 2006. Maximum body size among insular Komodo dragon populations covaries with large prey density. Oikos, 112: 422-429.

Jost, L. 2006. Entropy and diversity. Oikos, 113: 363-375.

Klawinski, P. D., Vaughan, R. K., Saenz, D. \& Godwin, W. 1994. Comparison of dietary overlap between allopatric and sympatric geckos. Journal of Herpetology, 28: 225-230.

Kusuminda, T. G. T., Athukorala, D. A. A. D. \& Karunarathna, D. M. S. S. 2013. Egg-predation of Hemidactylus frenatus. Taprobanica, 05: 152-153.
Lemos-Espinal, J. A. \& Dixon, J. R. 2013. Amphibians and reptiles of San Luis Potosí. Eagle Mountain Publishing, LC, Eagle Mountain, Utah, 300 pp.

Locey, K. J. \& Stone, P. A. 2008. Ontogenetic factors affecting diffusion dispersal in the introduced Mediterranean Gecko, Hemidactylus turcicus. Journal of Herpetology, 42: 593-599.

Magnusson, W. E., Lima, A. P., Alves da Silva, W. \& Carmozina de Araújo, M. 2003. Use of geometric forms to estimate volume of invertebrates in ecological studies of dietary overlap. Copeia, 2003: 13-19.

McCoid, M. J. 1994. Eggs, hatchling sizes, and oviposition sites of lizards on Guam, Mariana Islands. Herpetological Review, 25: 98100.

McNeely, J. A., Mooney, H. A., Neville, L. E., Schei, P. \& Waage J. K. 2001. A Global Strategy on Invasive Alien Species. IUCN Gland, Switzerland, and Cambridge, UK, 50 pp.

Moreno, C. E., Barragán, F., Pineda, E. \& Pavón, N. P. 2011. Reanalyzing alpha diversity: alternatives to understand and compare information about ecological communities. Revista Mexicana de Biodiversidad, 82: 1249-1261.

Park, K. 2004. Assessment and management of invasive alien predators. Ecology and Society, 9: 12.

Pianka, E. R. 1973. The structure of lizard communities. Annual Review of Ecology and Systematics, 4: 53-74.

Pianka, E. R. 1974. Niche overlap and diffuse competition. Proceedings of the National Academy of Sciences, 71: 2141-2145.

Pianka, E. R., Oliphant, M. S. \& Iverson, Z. L. 1971. Food habits of albacore, bluefin tuna, and bonito in California waters. California Department of Fish and Game Bulletin, 152: 1-350.

Ponce-Campos, P. \& Huerta-Ortega, S. M. 2001. Geographic distribution: Gehyra mutilata. Herpetological Review, 32: 57.

Quay, W. B. 1974. Notes on the winter reproductive biology of the gecko, Peropus mutilatus, on Kauai, Hawaiian Islands. Copeia, 1974: 254.

Quijada-Mascareñas, A. \& Canseco-Márquez, L. 2007. Geographic distribution: Gehyra mutilata. Herpetological Review, 38: 483.

Reynoso, F. 1990. Geographic distribution: Gehyra mutilata. Herpetological Review, 21: 22.

Rocha, S., Ineich, I. \& Harris, D. J. 2009. Cryptic variation and recent bipolar range expansion within the Stumped-Toed Gecko Gehyra mutilata across Indian and Pacific Ocean islands. Contributions to Zoology, 78: 1-8.

Sabath, M. D. 1981. Gekkonid lizards of Guam, Mariana Islands: reproduction and habitat preference. Journal of Herpetology, 15: 71-75.

Saenz, D. 1996. Dietary overview of Hemidactylus turcicus with possible implications of food partitioning. Journal of Herpetology, 30: 461-466.

Sanchez, M. 2010. The Reunion Day Gecko, Phelsuma borbonica Mertens, 1942 cannibalism behaviour (Sauria: Gekkonidae). Cahiers scientifiques de l'océan Indien occidental, 1: 1-2.

Schwaner, T. D. 1980. Reproductive biology of lizards on the American Samoan Islands. Occasional Papers of the Museum of Natural History, The University of Kansas, 86: 1-53.

Smith, H. M. \& Grant, C. 1958. Noteworthy Herptiles from Jalisco, Mexico. Herpetologica, 14: 18-23.

Smith, H. M. \& Taylor, E. H. 1950. An annotated checklist and key to the reptiles of Mexico exclusive of the snakes. Bulletin of the United States National Museum, 199: 1-254. 